\title{
Rapid Retreat of the Pacific Maritime Forest
}

George Kral ${ }^{1}$, Melodie Putnam ${ }^{1}$, David Rupp ${ }^{2}$

\begin{abstract}
The temperate maritime climate of the Pacific Northwest region of the United States supports the world's tallest and most economically productive conifer forests. These forests are vital to local ecosystems and society, and climate perturbations are likely to adversely affect the services these forests provide. This study presents a simple, easily replicated methodology for assessing effects of climate change in these local forests, using species with differential climatic ranges as ecological barometers. A comparative analysis of warm-adapted and cool-adapted species cooccurring within a warming but otherwise climatically homogenous area near the southeast margin of the Pacific maritime forest reveals dramatic differences in tree health and mortality between these climatically differentiated species groups. Our results strongly suggest a rapid decline at the southeastern extent of the Pacific maritime temperate forest, and a need to immediately modify local land management practices to address this new reality.
\end{abstract}

Keywords: climate change, forest ecology, tree decline, forest pathology, range dynamics, biogeography

${ }^{1}$ Oregon State University, Department of Botany and Plant Pathology

${ }^{2}$ Oregon State University, College of Earth, Ocean, and Atmospheric Sciences 


\section{Introduction}

2 Temperate and boreal forests are economically and ecologically vital. The temperate maritime

3 forests of northwestern North America are of particular economic importance; the Pacific Slope

4 forests of Oregon, Washington and northern California alone contain a third of the total softwood

5 volume of the United States (Oswalt 2014). In Canada, approximately 40 percent of all timber

6 produced in 2018 came from Pacific Slope forests (Natural Resources Canada 2018). Because of

7 their ecological and economic importance, there has been much conjecture regarding potential

8 response of these and other temperate forest systems to climate change (Daniels 2011, Hamann

9 2006, Vose 2012, Terrier 2013, HilleRisLambers 2015, Carnicer 2013, Keane 2001).

10 While numerous studies predict or document forest declines and die-off events in the arid west

11 (Allen and Breshears 1998, Breshears 2005, Adams 2009, Allen 2010, Smith 2015, Clifford

12 2013, Goulden 2019), there have been relatively few studies investigating actual climate-

13 associated forest responses in temperate systems, and the findings of these studies have been

14 mixed. Some studies indicate a climate change influence on temperate forests. Monleon (2015),

15 for instance, found modest but significant overall tendencies toward upward and northerly range

16 shifts of tree taxa on the western coast of North America by comparing differential elevational

17 and latitudinal distribution of mature trees and their progeny, although some of the evidence was

18 equivocal or even contradictory. Looking at the entire eastern United States, Woodall (2009)

19 identified significant northerly migration trends in northerly-ranging versus southerly-ranging

20 species, with northward migration rates estimated as high as $1 \mathrm{~km}$ per year. In a study of 76 long-

21 term forest plots in the western US, van Mantgem (2009) found significant increases in tree

22 mortality across all species in California, the Pacific Northwest, and the interior West. 
23 A subsequent investigation in western Washington, however, found no significant increase in

24 tree mortality looking at some of the same forest types (Acker 2015). Monleon (2015), Woodall

25 (2009) and other similar studies rely on snapshot differences in the distribution of seedlings and

26 saplings versus mature trees as evidence of shifting ranges. The assumption that these differences

27 are climate-driven is challenged by Máliš (2016) who presents evidence that the offset ranges of

28 tree progeny are more driven by ontogenetic effects, such as differential niche occupancy

29 between seedlings and mature trees, than by changing climate. Leak (2012) found no evidence

30 of range shifts in long-term forest plot data of easten hemlock (Tsuga canadensis) and red spruce

31 (Picea rubens), or in upslope seedling recruitment of several species of hardwoods and conifers

32 in the northeastern US. Generally, observational data have suggested that shifts in extent and

33 composition of temperate forests have been slow to occur in the absence of acute disturbance,

34 and some researchers have concluded that increased temperature is unlikely to be a singular

35 driver in tree species decline and migration in temperate forests, at least in the near term

36 (HilleRisLambers 2015, Leak 2012).

37 Even in temperate forests, however, increasing temperatures may exacerbate the effects of 38 periodic drought, insects and pathogens. Synergistic interactions of these factors have been

39 implicated in a number of cases of widespread tree die-offs in more arid regions (Breshears

40 2005, Adams 2009, Smith 2015, Goulden 2019). These and other studies of tree die-offs and

41 forest declines are congruent with the hypothesis that increasing temperatures and severity of

42 periodic drought could erode the southerly margins of northern hemisphere temperate forests.

43 The presence of a particular species provides direct evidence that climatic conditions at the time

44 of its establishment at a given locality were within the tolerances of the species as a whole.

45 Likewise, a species decline at that locality suggests that one or more environmental variables 
46 have moved beyond that species' tolerance. Individually, one species' decline or local extinction

47 provides limited circumstantial evidence of any particular environmental change. Multiple

48 species in decline, however, present an opportunity to analyze commonalities in declining

49 species' habitat requirements. These kinds of observations and analyses can identify local

50 impacts of environmental change and provide evidence-based guidance for model refinement

51 and on-the-ground decision making.

52 As an example, striking levels of tree decline and mortality in the Willamette Valley, Oregon,

53 U.S., are readily visible and of growing concern to foresters (Withrow-Robinson 2018, Oregon

54 Department of Forestry 2019). Tree decline and mortality have become apparent only in certain

55 species, however, and not others (Fig. 1). In this study, we examine the condition of four temperate maritime species and four Mediterranean climate-adapted species co-occurring in the

57 Willamette Valley. We sampled 674 individual trees in 55 stands and assessed the health of each

58 tree. We also cultured tissue samples from declining black hawthorn trees to rule out acute

59 pathogenic causation for observed decline in this species, a decline which has not previously

60 been investigated. We analyzed and compared the current condition of northerly-ranging and

61 southerly-ranging tree species to determine if patterns emerged relative to species ranges.

\section{Methods}

64 As a model system for investigating climate impacts in forests, the Willamette Valley presents an 65 opportunity for side-by-side performance evaluations of northward-ranging and southward66 ranging species in a warming climate. The Willamette Valley is transitional between the 67 temperate maritime climate zone to the north and the Mediterranean climate to the south, and 
68 elements of both temperate and Mediterranean plant communities can be found here, growing

69 together (OregonFlora 2020).

70 The climate of the Willamette Valley has become markedly warmer in recent decades compared

71 to most of the previous century, consistent with the larger regional pattern (Abatzoglou et al.,

72 2014; Oregon Climate Change Research Institute 2019). Since 1990, especially acute

73 temperature increases have emerged in mid and late-summer, coincident with an intensification

74 of the annual summer dry season.

75 Examining the records from the three stations that latitudinally span the Willamette Valley floor

76 reveals a clear pattern of recent elevated summer temperatures compared to a 1920-1990

77 baseline (Figure 2) when most natural forest stands in the Willamette Valley became established,

78 including all but one of the stands surveyed in this investigation. Averaging over the three

79 stations, the five-year mean summer (July-August) temperature for both 2002-2006 and 2014-

802018 was about $1.7^{\circ} \mathrm{C}$ above baseline. As a measure of how extreme this anomaly is, $1.7^{\circ} \mathrm{C}$

81 amounts to 2.7 standard deviations of the 1920-2019 five-year moving average of summer

82 anomalies. At the annual-scale, the 3-station mean summer temperature was below seasonal

83 norm only three times in the last three decades (1990-2019), and of the eleven warmest summers

84 since 1920, four were since 2014 (2014, 2015, 2017, and 2018).

85 Along with elevated temperatures, persistent deficits in summer precipitation have emerged since

862000 (Figure 2). July-August rainfall averaged over the same three stations during this period

87 was $60 \%$ of normal (1940-1990 baseline). It is worth noting that from 1940 to 1946 and 1951 to

88 1964, the 5-year moving average of July-August precipitation was also below average. Unlike

89 the recent long-term summer meteorological drought, however, over most of this earlier period, 
below-average summer precipitation was associated with near or below-average summer temperature.

92 The combination of high temperature and low humidity can be expressed through high vapor 93 pressure deficit (VPD). High VPD can stress trees and, when high enough, lead to hydraulic

94 failure and mortality (Bréda et al., 2006; Eamus et al., 2013; McDowell et al., 2008). In the

95 Pacific Northwest, high VPD has been associated with recent decreased growth of Douglas fir 96 (Psuedotsuga menziesii) (Restaino et al., 2016). Reliable estimates of VPD for the Willamette

97 Valley at a small number of stations can be made back only to 1948 based on (Daly et al., 2015) and those data include some substantial gaps. Despite these limitations, estimates of July-August mean daily maximum VPD (VPDmax) at three stations that latitudinally span much of the Willamette Valley indicate a prolonged period of above-average summer VPDmax since 2002 relative to a 1948-1990 baseline (Figure 3). VPDmax was particularly high during several years of the last decade; the years with the highest summer VPDmax since 1948 were 2015, 2018, 2017 and 2014 (in descending order), averaged over the three stations. The five-year moving averages of these data indicate the kind of persistent heat and drought stress which Buotte (2018), Daniels (2011) and others have linked with decreased allocation of tree resources to growth, tree decline and increased tree mortality.

107 Concurrent with the prolonged and ongoing period of warming and, over the last two decades, 108 the intensification of summer drought, there has been large-scale tree mortality throughout the 109 Willamette Valley (Withrow-Robinson 2018, Buhl 2017). Symptoms of tree decline have 110 appeared in certain tree taxa, however, and not others. Some of the first trees to exhibit 111 widespread decline were black hawthorn (Crataegus gaylussacia). Necrotic tissue from dead and 112 dying hawthorns submitted to the Oregon Department of Forestry for pathogen analysis between 
113 2006-2008 exhibited no identifiable acute pathogens at that time (Alan Kanaskie, Oregon

114 Department of Forestry, unpublished data). Since 2010, observers have identified several other

115 woody taxa showing signs of decline in the Willamette Valley, including western redcedar

116 (Thuja plicata), grand fir (Abies grandis), red alder (Alnus rubra) and others (Oregon State

117 University Extension Service 2018, Oregon Department of Forestry 2019, Sims 2015). All of

118 these declining species share similar distributions in areas with cool, moist, moderate climates.

119 They range from the Alaska panhandle or western British Columbia southward through western

120 Montana, northern Idaho, western Washington and Oregon, and coastal California (Fig. 4, right

121 panel). Indicative of the range of these species are narrow extensions southward along the

122 northern and central California coastal strip, where historically, summer temperatures have been

123 reliably cool. They are rare or absent in the Columbia Basin, interior Klamath region, the Sierra

124 Nevada foothills and other interior portions of California (Consortium of Pacific Northwest

125 Herbaria 2020, CalFlora 2020).

126 Meanwhile, several tree species with more southerly and interior ranges co-occur in the

127 Willamette Valley with temperate maritime species (Fig. 4, left panel). These more southerly

128 species are performing relatively well and do not exhibit evidence of decline. All of these species

129 share broad ranges in interior portions of California, and also in the comparatively warm and dry

130 Columbia Basin and the Snake River Valley (Consortium of Pacific Northwest Herbaria 2020,

131 CalFlora 2020. Little 1971).

132 Stand and Sample Tree Selection $\backslash$

133 For all species except white alder, survey stands were selected along north-south and east-west 134 transects through the Willamette Valley (Fig. 5). In some cases, it was possible to survey 135 multiple species within a single survey stand. From the beginning point of each transect, the first 
136 stand of each species encountered was surveyed. Following every 16-km increment thereafter

137 along the transect, the first accessible stand was surveyed. For white alder, which has a very

138 sporadic distribution within the study area, sample data was collected from seven study stands

139 broadly distributed throughout the Willamette Valley.

140 Distributional differences among the species required different sample sizes per survey point.

141 Stand-forming species often presented large numbers of individuals from which to select. In

142 these cases, up to 25 trees (10 trees for hawthorn) per sample point were assessed. Only

143 dominant and co-dominant individuals in stands, well-established saplings (minimum diameter

$1445 \mathrm{~cm}$ ), free-to-grow individuals not suppressed by competing vegetation, and formerly

145 dominant/codominant, recently dead class I snags (characterized by sound sapwood, intact fine

146 branches and tight bark, Cline 1980) were assessed. Trees and snags were selected and assessed

147 simply as they were encountered. Once the maximum sample number of encountered individuals

148 was reached, or all of the available trees had been assessed, the survey for that species was

149 concluded at that survey point.

151 Each tree was assessed for indicators of crown decline, including top dieback, branch flagging,

152 chlorosis/crown thinning, epicormic branching, and mortality. Other conditions such as bleeding

153 cankers were noted on individual trees. A 0.2-point deduction was assessed for every decline

154 indicator. Perfectly healthy trees with no decline indicators received a score of 1 . Dead

155 individuals received a score of 0 . Trees were rated as good (score $>0.7)$, fair $(0.7>=$ score $>$

$1560.4)$, poor $(0.4>=$ score $>0)$, and dead $($ score $=0)$.

\section{Pathogen Investigation}


158 To investigate the possibility of an acute, emerging pathogen in rapidly declining black hawthorn

159 stands, samples of root, trunk or branch tissue from 14 individuals showing moderate to

160 advanced decline systems were evaluated for known pathogenic organisms. Samples were

161 examined visually and microscopically for evidence of fungal or bacterial disease such as branch

162 or trunk cankers, root rot, crown rot, or other symptoms of biotic disease. Select tissue showing

163 distinct and sharp transitions from healthy to necrotic areas and those without such transitional

164 zones were sampled, disinfected in 10\% household bleach (1:9 bleach:water) for 3 minutes,

165 rinsed, and air dried under a laminar flow hood until no free moisture was visible. Tissue from

166 canker margins, when present, or from the region nearest the area of dieback when no cankers

167 were present, was sub-sampled and aseptically placed on water agar $(1.5 \%)$ and $1 / 4$ strength

168 potato dextrose agar containing $100 \mathrm{ppm}$ streptomycin to culture for fungi. Culture plates were

169 incubated at $20{ }^{\circ} \mathrm{C}$ for $7-14$ days or until sporulation occurred. Fungal cultures were identified

170 based on their morphology.

\section{$171 \underline{\text { Results }}$}

Stand and Tree Condition

173 Dramatic difference in tree condition and rates of mortality are apparent between temperate

174 maritime and Mediterranean tree species surveyed (Figures 6 and 7). On average, 30\% of

175 temperate maritime trees have recently died, and only $30 \%$ are in good condition (Figure 8, table

177 have recently died.

178 In each of the temperate maritime species, mortality was observed in all age and size classes, and

179 no trends emerged in rates of mortality among the classes: mature trees, poles and saplings are 
180 all currently subject to high rates of mortality. All mortality noted in this study is estimated to

181 have occurred within the past five years based on observations of mass tree mortality by foresters

182 (Buhl 2016, Oregon Department of Forestry 2019, Oregon State University Extension Service,

183 2018) and the low degree of bark exfoliation and other characteristics of dead trees surveyed

184 (class I snags only). This estimate is likely conservative based on Cline (1980). Cline estimates

185 that the average time of transition from decay class I to decay class II occurs within 5 years post

186 mortem in western Oregon Douglas-fir, which is a highly resinous tree with more durable bark

187 relative to the four Pacific maritime species in this study. Additionally, Cline's dataset only

188 includes trees $>9 \mathrm{~cm} \mathrm{DBH}$, while the current study includes trees as small as $5 \mathrm{~cm}$ diameter,

189 which typically decay much faster than larger trees (Vanderwel 2006). We estimate that the

190 observed $30 \%$ total mortality rate, therefore, equates to at least $6 \%$ annual mortality on average

191 across cool-adapted species between 2015-2019 (table1).

192 Pathogen Analysis in Black Hawthorn

193 Samples from 14 declining trees resulted in no one significant pathogen found in common

194 among the plants assayed (Table 2). We did not recover any bacterial pathogens from the

195 material (data not shown). The fungi recovered from tissues were largely saprophytic

196 (Cladosporium, Fusarium), weak or opportunistic (Epicoccum, Botrytis, Diaporthe) or are

197 pathogens often found in association with trees suffering from chronic stress (Diplodia,

198 Cytospora, Botryosphaeria). The latter fungi can cause significant damage to affected plants, but

199 are not considered capable of primary pathogenesis unless the plant is already compromised. The

200 role of Diaporthe eres in hawthorn is unknown, although this fungus can be a pathogen to

201 conifers and other woody plants.

202 Discussion 
203 The apparent absence of acute pathogen effects in black hawthorn mirrors findings of a previous

204 investigation of declining alder in western Oregon, in which Sims (2015) found little evidence of

205 acute pathogens, but rather several stress-associated insects and pathogens consistent with

206 environmentally driven decline. Likewise, a recent advisory on dead and dying western redcedar

207 by the Oregon Department of Forestry cites environmental stress as the cause of this decline

208 rather than any acute pathogen (Oregon Department of Forestry 2019). The evidence presented

209 here suggests environmental decline, and the data are clear that the decline is limited to cool-

210 adapted trees. Decline of not just one, but four important tree species at their southerly and

211 interior range margins, when coupled with climate data showing sharp increases in mean annual

212 temperature and decreases in precipitation, provides compelling evidence of a broad, climate-

213 related plant community shift, one with potential to affect the extent of some of the most

214 productive forests in the world.

215 Abram et al (2016) trace the inception of detectable North American warming associated with

216 land conversion and industrialization to the mid-19 $9^{\text {th }}$ century. In the intervening $\sim 170$-year

217 period, there is no record of any change in the arborescent flora of the Willamette Valley. Now,

218 after over a century and a half of increasing continental temperatures, several northerly

219 arborescent species in the Willamette Valley are declining at rates that threaten their existence in

220 this region in the near-term. If the rates of mortality estimated in this study continue, over half of

221 the red alder and grand fir and a quarter of the black hawthorn and western redcedar present in

222 the Willamette Valley in 2014 will be dead by 2025. If current temperature trends also continue

223 their upward ascent, these species are likely very soon to cease to exist in this region. This

224 outcome would corroborate projections from dynamic vegetation models showing substantial

225 reductions in softwood in favor of hardwood/mixed forests (e.g., Hawkins et al., 2019; Sheehan 
et al., 2015; Turner et al., 2015) though those projections span a large of range outcomes due to uncertainties in future climate and model parameterizations (e.g., Hawkins et al., 2019; Shafer et al., 2015) Tree decline and mortality appear to be not just lagging indicators of climate change, but extremely delayed ones, suggesting the possibility of continued and accelerating emergence of costly and environmentally deleterious climate-driven range shifts in this region.

Most predicted plant community response to climate change is based on large-scale models of exceedingly complex systems. As Hamann (2006) concludes, “(if) currently observed climate trends continue or accelerate, major changes to management of natural resources will become necessary. Because of modeling uncertainties at small spatial scales, systematic field monitoring of biological response to climate change guided by our model predictions may be the best indicator for the need to implement management changes." The simple approach presented here provides a means to rapidly assess local climate effects, and to inform species selection for nursery propagation and out-planting in the Willamette Valley. The same or similar methodologies can be replicated at any locality where significant climate change is occurring to assess its ecological effects and provide a basis for local land management decision making and on-the-ground action.

\section{References}

Abatzoglou, J. T., D. E Rupp, \& P. W. Mote. 2014. "Seasonal Climate Variability and Change in the Pacific Northwest of the United States." Journal of Climate, 27(5): 2125-2142. https://doi.org/10.1175/JCLI-D-13-00218.1.

Abram, Nerile J., Helen V. Mcgregor, Jessica E. Tierney, Michael N. Evans, Nicholas P. Mckay, and Darrell S. Kaufman. 2016. "Early Onset of Industrial-era Warming across the Oceans and Continents." Nature 536, no. 7617: 411-8.

Acker, Steven A., Boetsch, John R., Bivin, Mignonne, Whiteaker, Lou, Cole, Carla, and Philippi, Tom. 2015. "Recent Tree Mortality and Recruitment in Mature and Old-growth Forests in Western Washington." Forest Ecology and Management 336: 109 
Adams, Henry D, Maite Guardiola-Claramonte, Greg A Barron-Gafford, Juan Camilo Villegas, David D Breshears, Chris B Zou, Peter A Troch, and Travis E Huxman. 2009. "Temperature Sensitivity of Drought-induced Tree Mortality Portends Increased Regional Die-off under Global-change-type Drought." Proceedings of the National Academy of Sciences of the United States of America 106, no. 17: 7063-7066.

Allen, C.D., and Breshears, D.D. 1998. "Drought-induced Shift of a Forest-woodland Ecotone: Rapid Landscape Response to Climate Variation." Proceedings of the National Academy of Sciences of the United States of America, no. 25: 14839-4842.

Allen, Craig D, Alison K Macalady, Haroun Chenchouni, Dominique Bachelet, Nate Mcdowell, Michel Vennetier, Thomas Kitzberger, Andreas Rigling, David D Breshears, E.H. Hogg, Patrick Gonzalez, Rod Fensham, Zhen Zhang, Jorge Castro, Natalia Demidova, JongHwan Lim, Gillian Allard, Steven W Running, Akkin Semerci, and Neil Cobb. 2010. "A Global Overview of Drought and Heat-induced Tree Mortality Reveals Emerging Climate Change Risks for Forests." Forest Ecology and Management 259, no. 4: 660-84.

Bréda, N., R Huc, A. Granier, \& E. Dreyer. 2006. “Temperate forest trees and stands under severe drought: a review of ecophysiological responses, adaptation processes and longterm consequences." Annals of Forest Science, 63(6): 625-644. https://doi.org/10.1051/forest:2006042

Breshears, David, Neil Cobb, Paul Rich, Kevin Price, Craig Allen, Randy Balice, William Romme, Jude Kastens, MLisa Floyd, Jayne Belnap, Jesse Anderson, Orrin Myers, and Clifton Meyer. 2005. "Regional Vegetation Die-off in Response to Global-change-type Drought." Proceedings of the National Academy of Sciences, USA 102, no. 42: 151445148.

Buhl, Christine, Alan Kanaskie, Sarah Navarro, Danny Norlander, Wyatt Williams, Zack Heath, Robert Schroeder, Ben Smith. 2017. "Forest Health Highlights in Oregon - 2016." USDA Forest Service Pacific Northwest Region Forest Health Protection and Oregon Department of Forestry Forest Health Program.

Buotte, Polly C, Levis, Samuel, Law, Beverly E, Hudiburg, Tara W, Rupp, David E, and Kent, Jeffery J. 2018. "Near $\square$ future Forest Vulnerability to Drought and Fire Varies across the Western United States." Global Change Biology 25, no. 1: 290-303.

Calflora: Information on California plants for education, research and conservation. [web application]. 2020. Berkeley, California: The Calflora Database [a non-profit organization]. Available: https://www.calflora.org/ (Accessed: May 23, 2020)

Carnicer, Jofre, Marta Coll, Miquel Ninyerola, Xavier Pons, Gerardo Sanchez, Josep Penuelas, and Olff Group. 2011. "Widespread Crown Condition Decline, Food Web Disruption, and Amplified Tree Mortality with Increased Climate Change-type Drought." Proceedings of the National Academy of Sciences of the United States of America 108, no. 4: 1474-478. 
Clifford, Michael J., Patrick D. Royer, Neil S. Cobb, David D. Breshears, and Paulette L. Ford. 2013. "Precipitation Thresholds and Drought $\square$ induced Tree Die $\square$ off: Insights from Patterns of Pinus Edulis Mortality along an Environmental Stress Gradient." New Phytologist 200, no. 2: 413-21.

Cline, Steven P., Alan B. Berg, and Howard M. Wight. 1980. "Snag Characteristics and Dynamics in Douglas-Fir Forests, Western Oregon." The Journal of Wildlife Management 44, no. 4: 773-86.

Daly, C., J. I. Smith, \& K. V. Olson. 2015. "Mapping atmospheric moisture climatologies across the conterminous United States." PLOS ONE, 10(10): e0141140. https://doi.org/10.1371/journal.pone.0141140

Daniels, Lori D., Thomas B. Maertens, Amanda B. Stan, Shane P. J. McCloskey, Jed D. Cochrane \& Robert W. Gray. 2011. "Direct and indirect impacts of climate change on forests: three case studies from British Columbia." Canadian Journal of Plant Pathology, 33:2: 108-116, DOI: 10.1080/07060661.2011.563906.

Eamus, D., N. Boulain, J. Cleverly, \& D. D. Breshears. 2013. "Global change-type droughtinduced tree mortality: vapor pressure deficit is more important than temperature per se in causing decline in tree health." Ecology and Evolution, 3(8): 2711-2729. https://doi.org/10.1002/ece3.664

Goulden, M., and R. Bales. 2019. "California Forest Die-off Linked to Multi-year Deep Soil Drying in 2012-2015 Drought." Nature Geoscience 12, no. 8: 632-37.

Hamann, Andreas, and Tongli Wang. 2006. "Potential effects of Climate Change on Ecosystem and Tree Species Distribution in British Columbia." Ecology 87, no. 11: 2773-786.

Hawkins, L. R., Rupp, D. E., McNeall, D. J., Li, S., Betts, R. A., Mote, P. W., Sparrow, S. N., \& Wallom, D. C. H. 2019. "Parametric Sensitivity of Vegetation Dynamics in the TRIFFID Model and the Associated Uncertainty in Projected Climate Change Impacts on Western U.S. Forests". Journal of Advances in Modeling Earth Systems, 11(8): 2787-2813. https://doi.org/10.1029/2018MS001577

Hille Ris Lambers, Janneke, D. L. Leander, I. B. Anderegg, K. M. Burns, A. K. Ettinger, J. F. Franklin, J. A. Freund, K. R. Ford, and S. J. Krolss. 2015. "Implications of Climate Change for Turnover in Forest Composition." Northwest Science 89, no. 3: 201-18.

Keane, Robert E., M. Austin, C. Field, A. Huth, M. J. Lexer, D. Peters, A. Solomon, and P. Wyckoff. 2001. "Tree Mortality in Gap Models: Application to Climate Change." Climatic Change: 509.

Leak, William B., Yamasaki, Mariko. 2012. "Tree Species Migration Studies in the White Mountains of New Hampshire." United States Department of Agriculture Forest Service Northern Research Station Research Paper NRS-19.

Little Jr, Elbert L. 1971. Atlas of United States trees, vol. 1: Conifers and important hardwoods. USDA Forest Service Miscellaneous Publication 1146. 
Máliš, F., Kopecký, M., Petř́k, P., Vladovič, J., Merganič, J., \& Vida, T.. 2016. "Life stage, not climate change, explains observed tree range shifts." Global Change Biology, 22(5): 1904-1914. https://doi.org/10.1111/gcb.13210

McDowell, N., Pockman, W. T., Allen, C. D., Breshears, D. D., Cobb, N., Kolb, T., Plaut, J., Sperry, J., West, A., Williams, D. G., \& Yepez, E. A. 2008. "Mechanisms of plant survival and mortality during drought: why do some plants survive while others succumb to drought?" New Phytologist, 178(4), 719-739. https://doi.org/10.1111/j.1469$\underline{8137.2008 .02436 . x}$

Menne, M. J., Durre, I., Vose, R. S., Gleason, B. E., \& Houston, T. G.. 2012. “An Overview of the Global Historical Climatology Network-Daily Database." Journal of Atmospheric and Oceanic Technology, 29(7): 897-910. https://doi.org/10.1175/JTECH-D-11-00103.1

Monleon, Vicente J., Heather E. Lintz, and Sylvain Delzon. 2015. "Evidence of Tree Species' Range Shifts in a Complex Landscape (Shifts in Tree Species Distributions)." Plos one 10, no. 1: E0118069.

Natural Resources Canada. 2018. "The state of Canada's forests: Annual report 2018."

Niemiec, Stanley S., and Oregon State University. Forest Research Laboratory. 1995. Hardwoods of the Pacific Northwest. Research Contribution (Oregon State University. Forest Research Laboratory) ; 8. Corvallis, Or.: College of Forestry, Forest Research Laboratory, Oregon State University: Available from Forestry Publications Office, Oregon State University.

Oregon Climate Change Research Institute, Issuing Body. 2019. "The Fourth Oregon Climate Assessment Report." Corvallis, Oregon: Oregon Climate Change Research Institute, Oregon State University.

Oregon Department of Forestry. 2019. "Why is my tree dying - western redcedar." Forest Benefits. April 2019. oregon.gov/ODF/Documents/ForestBenefits/TreeDeclinesRedcedar.pdf

Oregon State University Extension Service. 2018. "Stressed trees show dieback" Forest Health and Management. March (2018). https://extension.oregonstate.edu/forests/healthmanagment/stressed-trees-show-dieback.

Oswalt, Sonja N., and United States Forest Service. 2014. Forest Resources of the United States, 2012 : A Technical Document Supporting the Forest Service Update of the 2010 RPA Assessment. General Technical Report WO ; 91. Washington, D.C.: United States Department of Agriculture, Forest Service.

Restaino, C. M., Peterson, D. L., \& Littell, J. 2016. “Increased water deficit decreases Douglas fir growth throughout western US forests." Proceedings of the National Academy of Sciences, 113(34): 9557-9562. https://doi.org/10.1073/pnas.1602384113

Shafer, S. L., Bartlein, P. J., Gray, E. M., \& Pelltier, R. T. 2015. "Projected Future Vegetation Changes for the Northwest United States and Southwest Canada at a Fine Spatial 
Resolution Using a Dynamic Global Vegetation Model.” PLOS ONE, 10(10): e0138759. https://doi.org/10.1371/journal.pone.0138759

Sheehan, T., Bachelet, D., \& Ferschweiler, K.. 2015. "Projected major fire and vegetation changes in the Pacific Northwest of the conterminous United States under selected CMIP5 climate futures." Ecological Modelling, 317: 16-29. https://doi.org/10.1016/j.ecolmodel.2015.08.023

Sims, Laura, Ellen Goheen, Alan Kanaskie, and Everett Hansen. 2015. "Alder Canopy Dieback and Damage in Western Oregon Riparian Ecosystems." Northwest Science 89, no. 1: 3446

Smith, Paritsis, Veblen, and Chapman. 2015. "Permanent Forest Plots Show Accelerating Tree Mortality in Subalpine Forests of the Colorado Front Range from 1982 to 2013." Forest Ecology and Management 341: 8-17.

Terrier, Aurélie, Martin P. Girardin, Catherine Périé, Pierre Legendre, and Yves Bergeron. 2013. "Potential changes in forest composition could reduce impacts of climate change on boreal wildfires." Ecological Applications 23, no. 1: 21-35.

Turner, D. P., Conklin, D. R., \& Bolte, J. P. 2015. "Projected climate change impacts on forest land cover and land use over the Willamette River Basin, Oregon, USA." Climatic Change, 133(2): 335-348. https://doi.org/10.1007/s10584-015-1465-4

Vanderwel, M.C., Malcolm, J.R., and Smith, S.M. 2006. “An integrated model for snag and downed woody debris decay class transitions." For. Ecol. Manage. 234: 48-59. doi:10.1016/j.foreco.2006.06.020.

Van Mantgem, Phillip J, Nathan L Stephenson, John C Byrne, Lori D Daniels, Jerry F Franklin, Peter Z Fulé, Mark E Harmon, Andrew J Larson, Jeremy M Smith, Alan H Taylor, and Thomas T Veblen. 2009. "Widespread Increase of Tree Mortality Rates in the Western United States." Science (New York, N.Y.) 323, no. 5913: 521-524.

Vose, James M., David L. Peterson, and Toral Patel-Weynand. 2012. "Effects of climatic variability and change on forest ecosystems: a comprehensive science synthesis for the US." Gen. Tech. Rep. PNW-GTR-870. Portland, OR: US Department of Agriculture, Forest Service, Pacific Northwest Research Station. 265: 870.

Withrow-Robinson, Brad. 2018 "Another rough year for Willamette Valley trees." Tree Topics (blog). June 13, 2018. http://blogs.oregonstate.edu/treetopics/2018/06/13/anotherrough-year-for-willamette-valley-trees-part-1.

Woodall, C.W, C.M Oswalt, J.A Westfall, C.H Perry, M.D Nelson, and A.O Finley. 2009. "An Indicator of Tree Migration in Forests of the Eastern United States." Forest Ecology and Management 257, no. 5: 1434-444. 
bioRxiv preprint doi: https://doi.org/10.1101/2020.08.31.273847; this version posted September 1, 2020. The copyright holder for this preprint (which was not certified by peer review) is the author/funder, who has granted bioRxiv a license to display the preprint in perpetuity. It is made available under aCC-BY 4.0 International license.

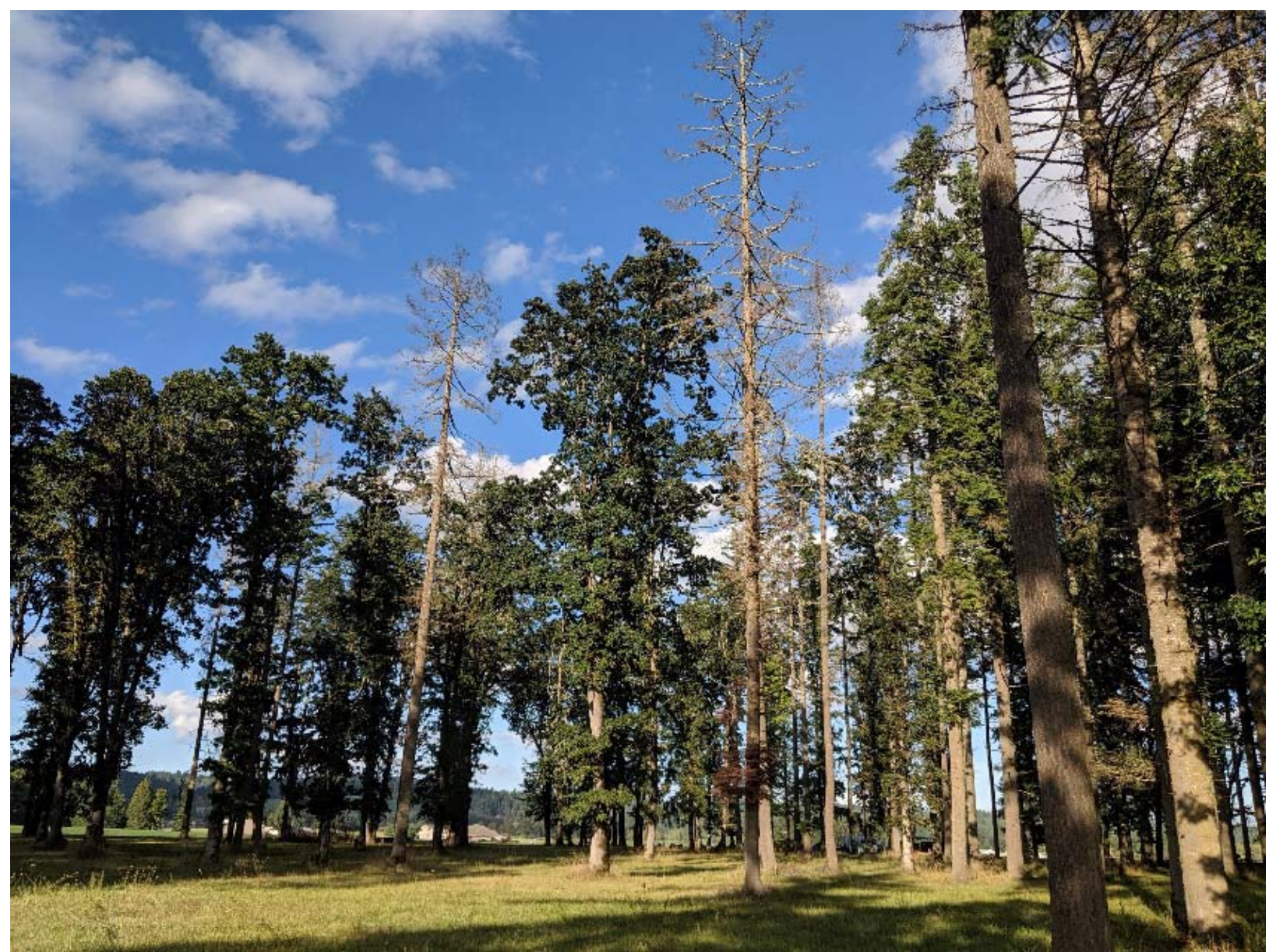

Figure 1: Mortality of grand fir in the Willamette Valley, Oregon in 2019. Note adjacent healthy Garry oaks. 
bioRxiv preprint doi: https://doi.org/10.1101/2020.08.31.273847; this version posted September 1, 2020. The copyright holder for this preprint (which was not certified by peer review) is the author/funder, who has granted bioRxiv a license to display the preprint in perpetuity. It is made available under aCC-BY 4.0 International license.
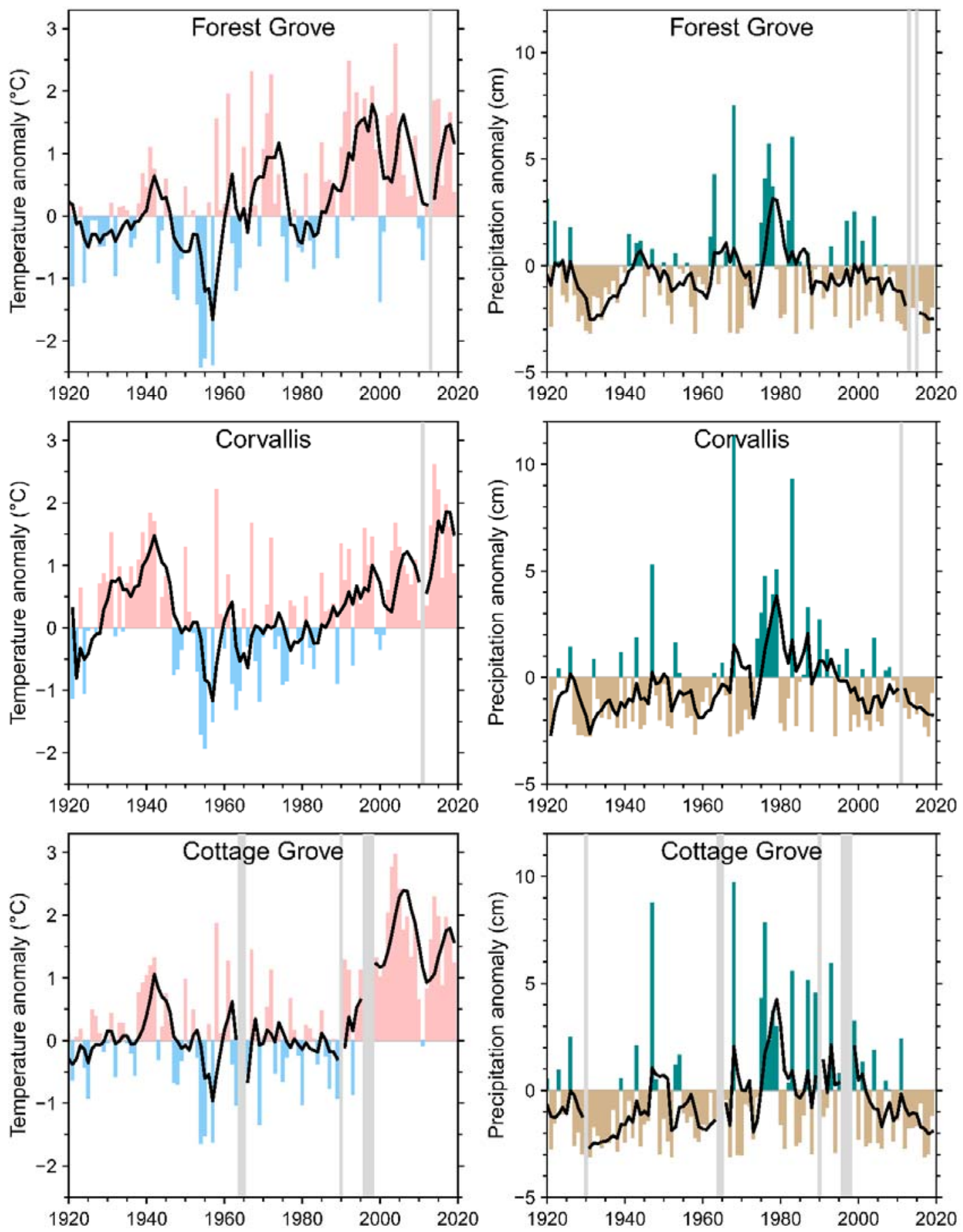

Figure 2. Left column: July-August mean temperature anomalies from a 1940-1990 baseline period at Forest Grove (station USC00352997), Corvallis (station USC00351862), and Cottage Grove (station USC00351897), Oregon. The black line shows the 5-year backward moving average of the temperature anomalies. Right column: Same as left column but for July-August total precipitation anomalies. July-August periods with more than 4 days of missing data were excluded (gray shading). Data source: Global Historical Climate Network (Menne et al., 2012) 
bioRxiv preprint doi: https://doi.org/10.1101/2020.08.31.273847; this version posted September 1, 2020. The copyright holder for this preprint (which was not certified by peer review) is the author/funder, who has granted bioRxiv a license to display the preprint in perpetuity. It is made available under aCC-BY 4.0 International license.
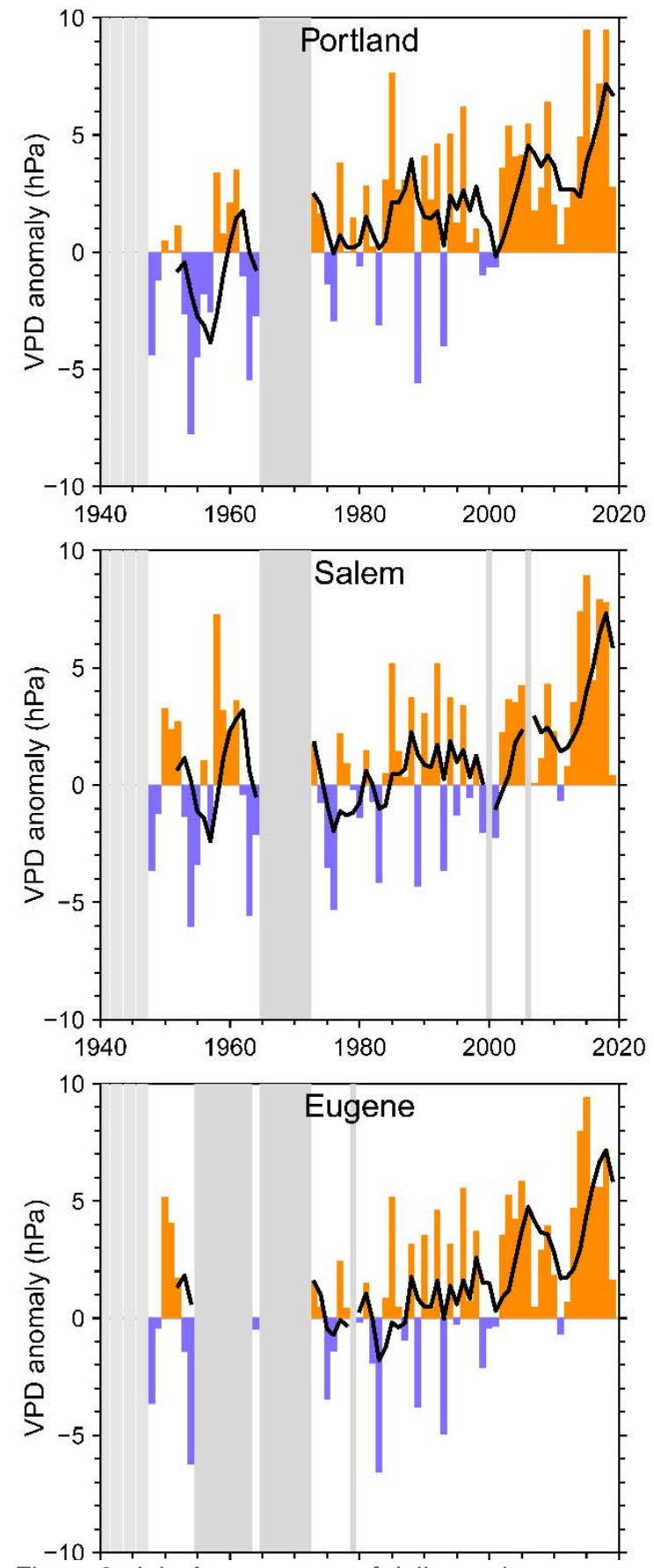

Figure 3. July-August mean of daily maximum vapor pressure deficit anomalies from 1940-1990 baseline period at Portland (station KPDX), Salem (station $K S L E)$, and Eugene (station KEUG), Oregon, airports The black line shows the 5-year backward moving average of the anomalies. July-August periods with more than 4 days of invalid data were excluded (gray shading). 
bioRxiv preprint doi: https://doi.org/10.1101/2020.08.31.273847; this version posted September 1, 2020. The copyright holder for this preprint (which was not certified by peer review) is the author/funder, who has granted bioRxiv a license to display the preprint in perpetuity. It is made available under aCC-BY 4.0 International license.

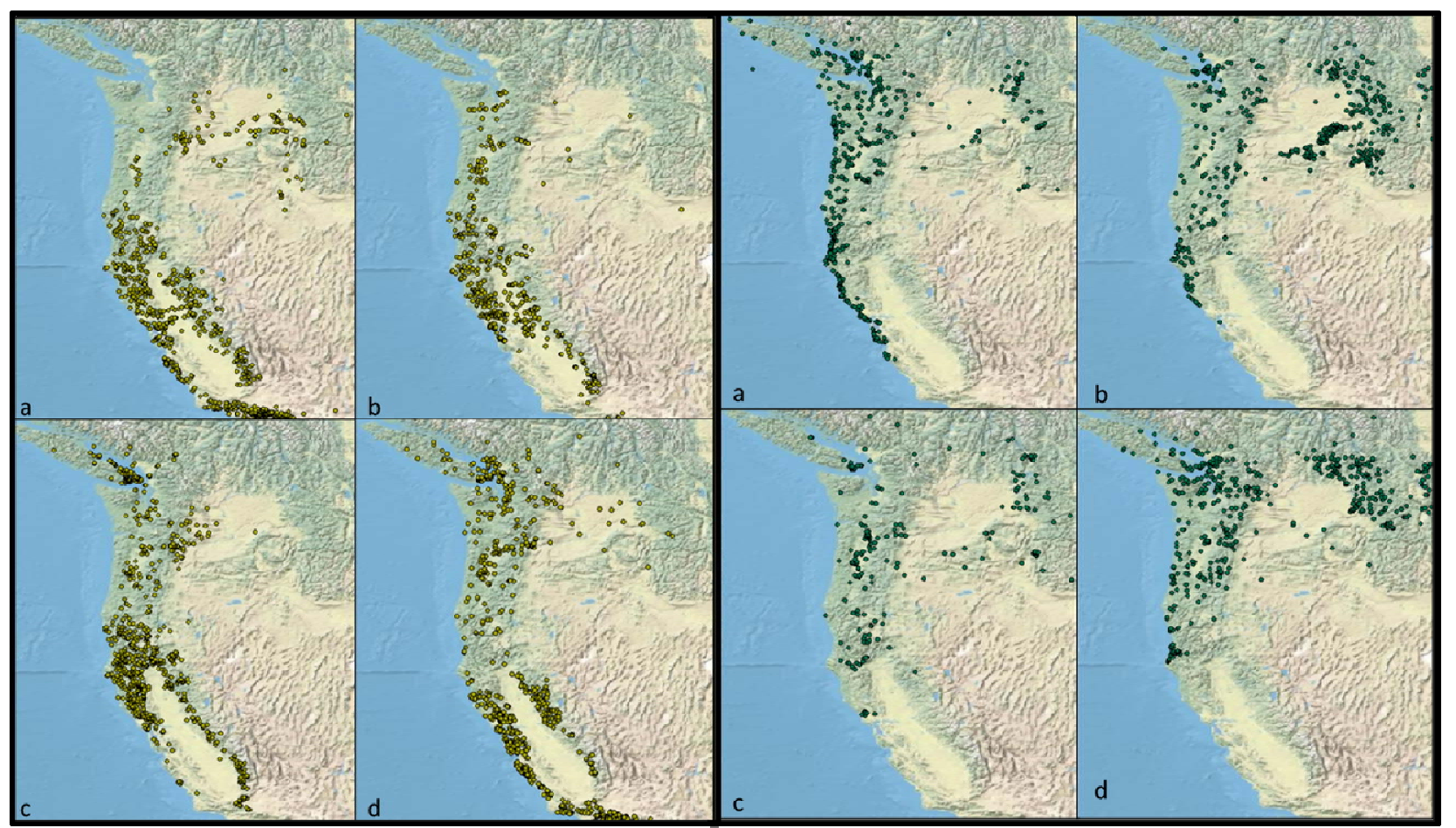

Fig 4: Distribution of four Mediterranean climate-adapted species:LEFT (a) Alnus rhombifolia (white alder) (b) Fraxinus latifolia (Oregon ash), (c) Quercus garryana (Garry oak), and (d) Acer macrophyllum (bigleaf maple), and four temperate maritime species RIGHT (a) Alnus rubra (red alder) (b) Abies grandis (grand fir) (c) Crataegus gaylussacia (black hawthorn) and (d) Thuja plicata (western redcedar) (data from CalFlora.org, PNWherbaria.org)

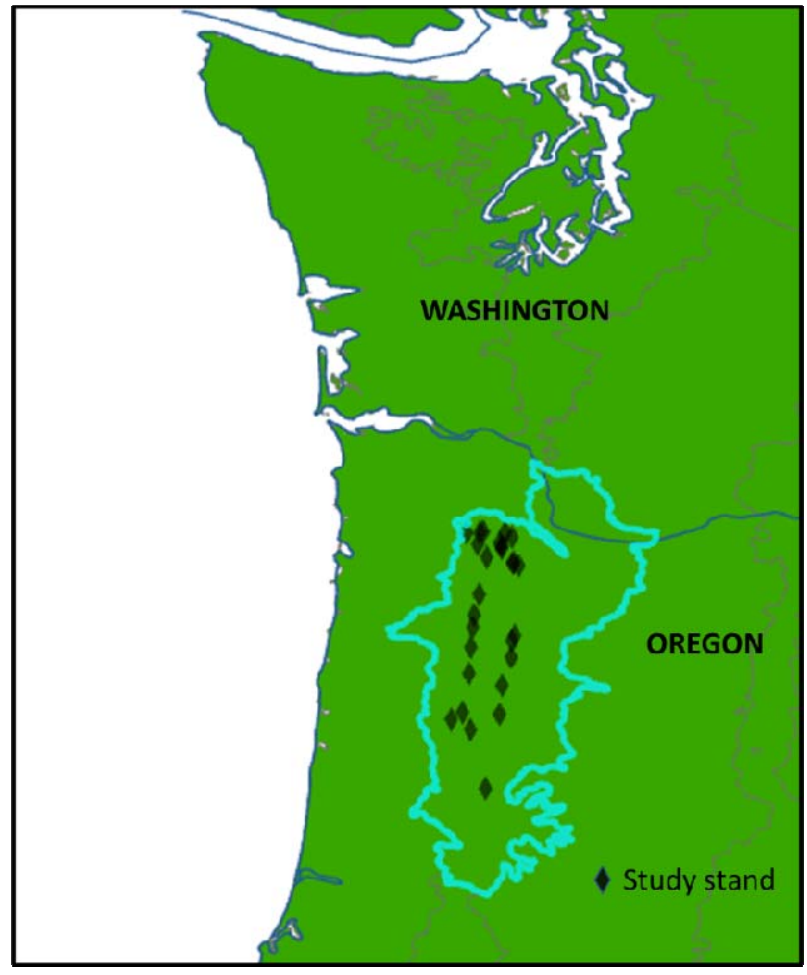

Figure 5: Willamette Valley ecoregion and stand survey locations 
bioRxiv preprint doi: https://doi.org/10.1101/2020.08.31.273847; this version posted September 1, 2020. The copyright holder for this preprint

(which was not certified by peer review) is the author/funder, who has granted bioRxiv a license to display the preprint in perpetuity. It is made available under aCC-BY 4.0 International license.

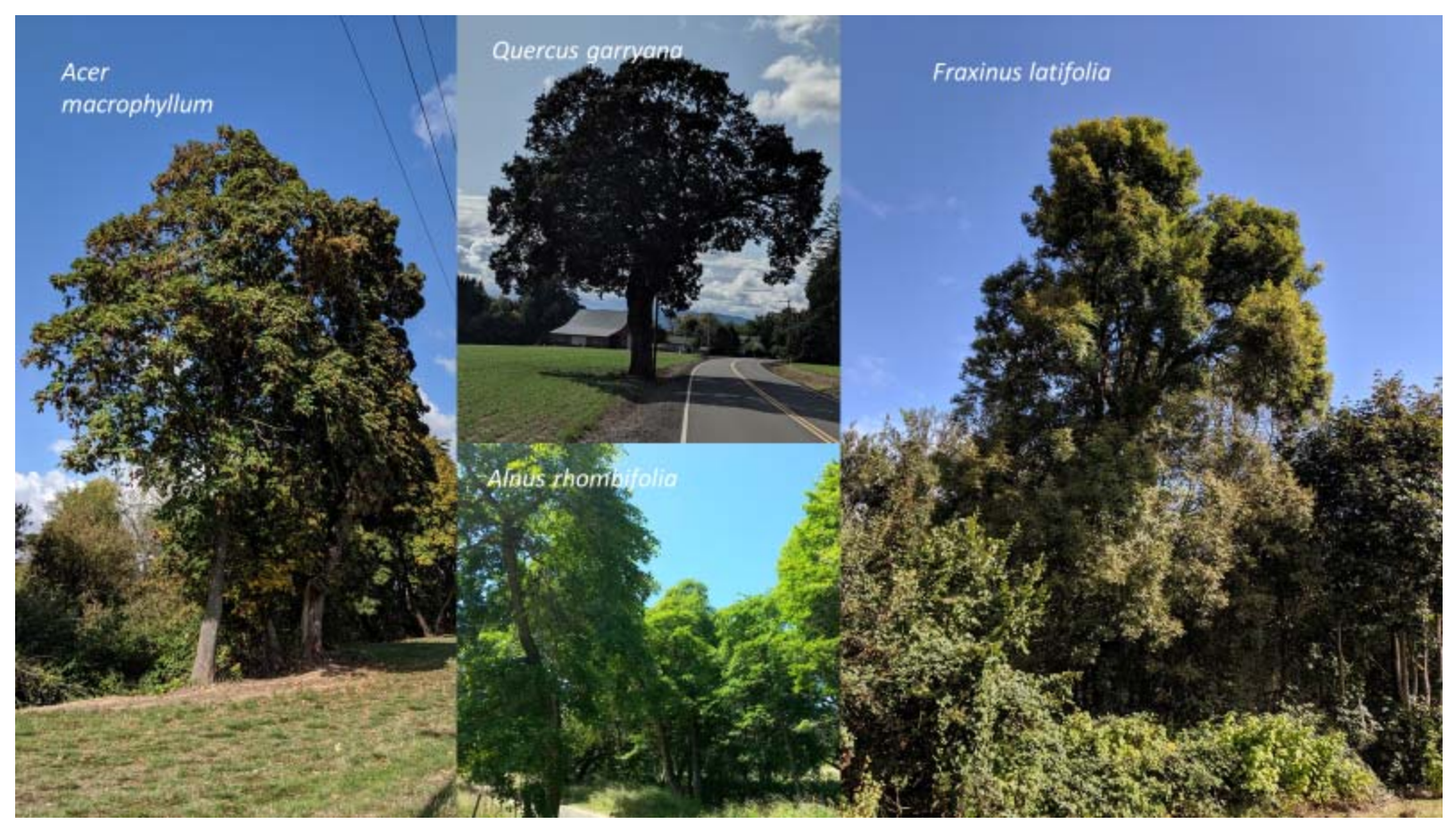

Figure 6: Typical specimens of southerly-ranging species within the study area. Note full, leafy crowns.

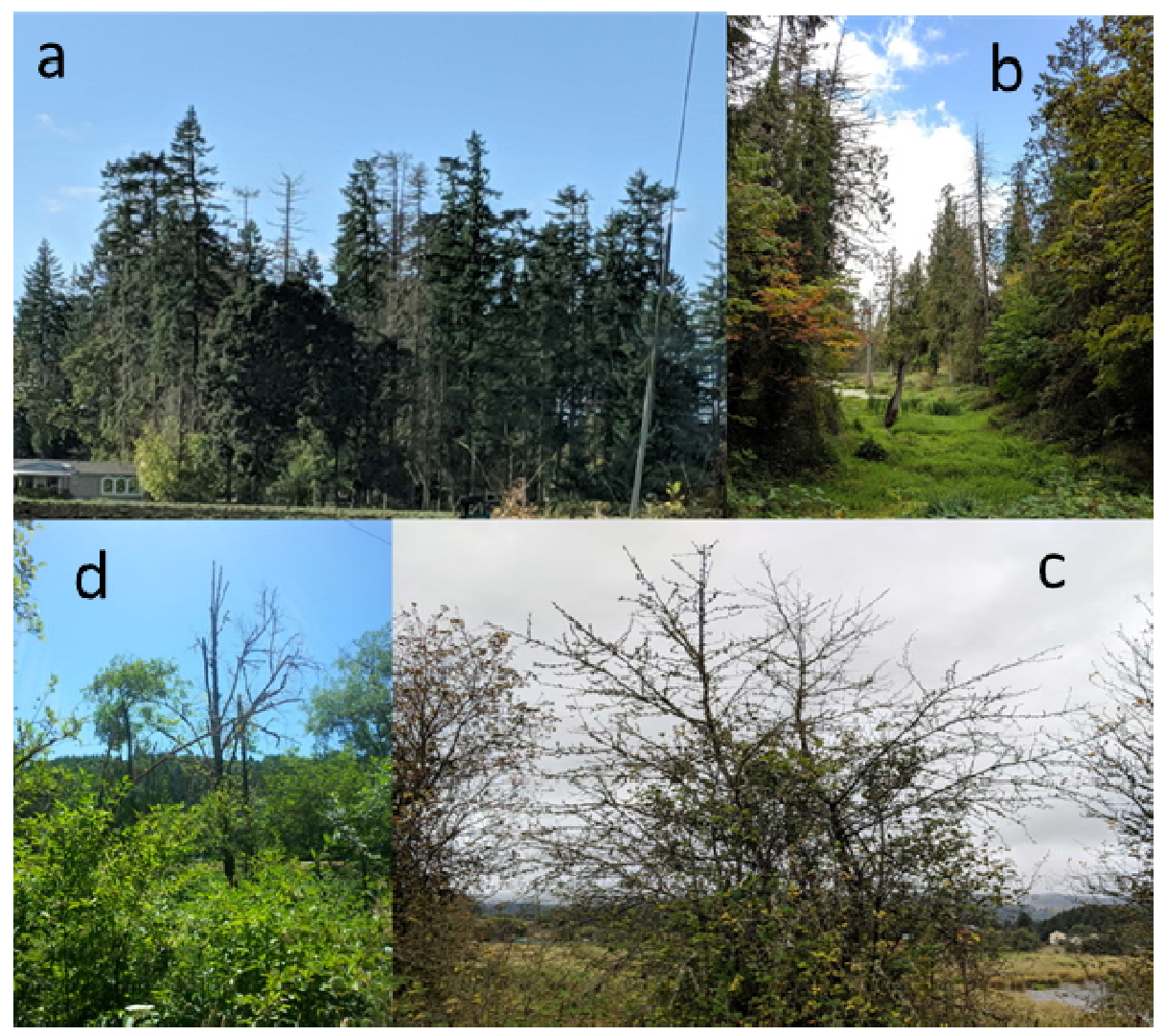

Figure 7: Typical decline in four temperate species. Clockwise from top left (a) grand fir in mixed stand with Pseudotsuga menziesii and Quercus garryana; (b) Western redcedar with Acer macrophyllum; (c) black hawthorn; and (d) red alder. 
bioRxiv preprint doi: https://doi.org/10.1101/2020.08.31.273847; this version posted September 1, 2020. The copyright holder for this preprint (which was not certified by peer review) is the author/funder, who has granted bioRxiv a license to display the preprint in perpetuity. It is made available under aCC-BY 4.0 International license.

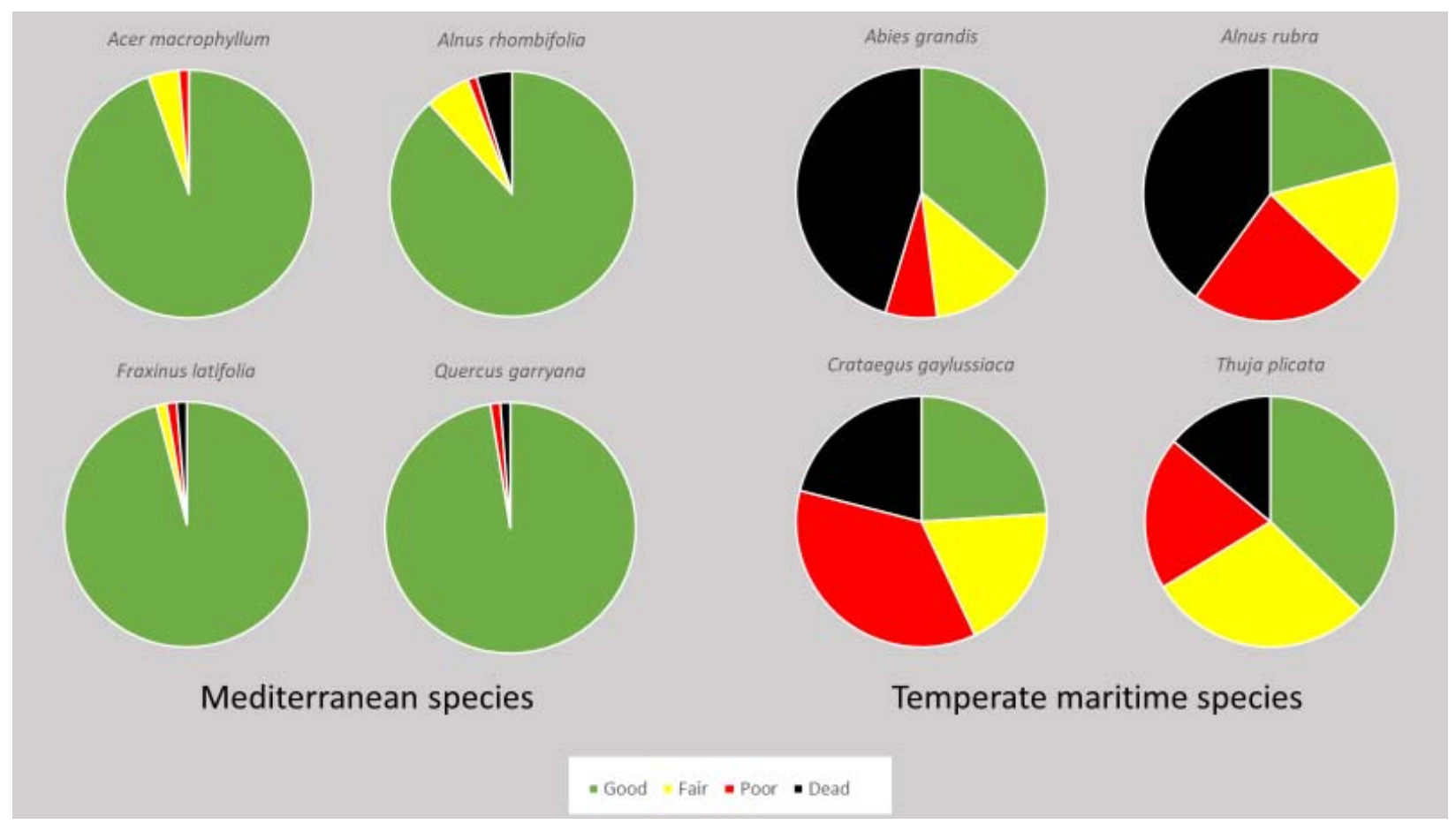

Figure 8: Comparison of Mediterranean (warm-adapted) and temperate maritime (cool-adapted) tree conditions in the Willamette Valley, Oregon 
Table 1: Sampling intensity and tree health analysis of four maritime-adapted and four Mediterranean climate-adapted species

\begin{tabular}{|c|c|c|c|c|c|c|c|}
\hline Species & $\begin{array}{l}\text { Trees } \\
\text { Sampled }\end{array}$ & $\begin{array}{l}\text { No. } \\
\text { Stand } \\
\text { s } \\
\end{array}$ & $\begin{array}{l}\text { Avg } \\
\text { Score }\end{array}$ & Good & Fair & Poor & Dead \\
\hline \multirow{4}{*}{$\begin{array}{l}\text { Abies grandis } \\
\text { Alnus rubra } \\
\text { Crataegus gaylussacia } \\
\text { Thuja plicata }\end{array}$} & 75 & 8 & 0.44 & $36 \%$ & $12 \%$ & $7 \%$ & $45 \%$ \\
\hline & 100 & 7 & 0.36 & $21 \%$ & $16 \%$ & $23 \%$ & $40 \%$ \\
\hline & 100 & 10 & 0.43 & $24 \%$ & $19 \%$ & $36 \%$ & $21 \%$ \\
\hline & 86 & 4 & 0.60 & $37 \%$ & $29 \%$ & $20 \%$ & $14 \%$ \\
\hline \multirow{4}{*}{$\begin{array}{l}\text { Acer macrophyllum } \\
\text { Alnus rhombifolia } \\
\text { Fraxinus latifolia } \\
\text { Quercus garryana }\end{array}$} & 75 & 5 & 0.95 & $95 \%$ & $4 \%$ & $1 \%$ & $0 \%$ \\
\hline & 85 & 7 & 0.86 & $88 \%$ & $6 \%$ & $1 \%$ & $5 \%$ \\
\hline & 75 & 4 & 0.95 & $96 \%$ & $1 \%$ & $1 \%$ & $1 \%$ \\
\hline & $\underline{78}$ & $\underline{10}$ & 0.97 & $97 \%$ & $0 \%$ & $1 \%$ & $1 \%$ \\
\hline \multirow[t]{2}{*}{ Total } & 674 & 55 & & & & & \\
\hline & & & & & & & \\
\hline temperate species & 361 & & $0.46^{\prime}$ & $30 \%$ & $19 \%$ & $21 \%$ & $30 \%$ \\
\hline Mediterranean species & 313 & & $0.93^{\prime}$ & $94 \%$ & $3 \%$ & $1 \%$ & $2 \%$ \\
\hline
\end{tabular}

Table 2: Sample dates, tissues examined, symptoms, and results of culturing from black hawthorn material showing decline symptoms

\begin{tabular}{|c|c|c|c|c|}
\hline Sample identifier & Date received & Tissue sampled & Symptoms & Outcome \\
\hline $17-1159$ & 5 July 2017 & Branch & Dieback & Diplodia \\
\hline $17-1492$ & 15 August 2017 & Branch & Tip dieback & Diaporthe \\
\hline $17-1516$ & 16 August 2017 & Branch & $\begin{array}{l}\text { Tip dieback, leaf } \\
\text { spots }\end{array}$ & $\begin{array}{l}\text { Mycocentrospora acerina } \\
\text { (leaves); Trichoderma sp., } \\
\text { Phoma sp. (branch) }\end{array}$ \\
\hline $17-2058$ & 2 November 2017 & Branch, root & $\begin{array}{l}\text { Cankers, root } \\
\text { necrosis, insect } \\
\text { feeding injury }\end{array}$ & $\begin{array}{l}\text { Cytospora sp. (branch, } \\
\text { root) }\end{array}$ \\
\hline $19-1693$ & 2 October 2019 & Branch, root & Dieback & Diaporthe eres (branch) \\
\hline $19-1775$ & 10 October 2019 & Branch & Dieback & Botryosphaeria sp. \\
\hline $19-1776$ & 10 October 2019 & Branch & Dieback & Cytospora sp. \\
\hline $19-1777$ & 10 October 2019 & Branch & Dieback & Botryosphaeria sp. \\
\hline $19-1778$ & 10 October 2019 & Branch & Dieback & Penicillium, sterile fungi \\
\hline
\end{tabular}


bioRxiv preprint doi: https://doi.org/10.1101/2020.08.31.273847; this version posted September 1 2020. The copyright holder for this preprint (which was not certified by peer review) is the author/funder, who has granted bioRxiv a license to display the preprint in perpetuity. It is made available under aCC-BY 4.0 International license.

\begin{tabular}{|c|c|c|c|c|}
\hline 19-1802 & 17 October 2019 & Branch, bark & $\begin{array}{l}\text { Tip dieback; bark } \\
\text { borers (bark piece). }\end{array}$ & $\begin{array}{l}\text { Cytospora sp., Fusarium } \\
\text { sp (branch). }\end{array}$ \\
\hline $19-1803$ & 17 October 2019 & Branch, bark & $\begin{array}{l}\text { Tip dieback; bark } \\
\text { necrosis }\end{array}$ & Diaporthe sp. \\
\hline $19-1804$ & 17 October 2019 & Bark & Necrosis & Diverse sterile fungi \\
\hline $19-1805$ & 17 October 2019 & Branch, bark & $\begin{array}{l}\text { Bark borers (bark } \\
\text { pieces) }\end{array}$ & $\begin{array}{l}\text { Penicillium, diverse sterile } \\
\text { fungi (branch) }\end{array}$ \\
\hline $19-1806$ & 17 October 2019 & Branch, bark & $\begin{array}{l}\text { Localized lesions, } \\
\text { bark borers (bark). }\end{array}$ & $\begin{array}{l}\text { Epicoccum sp., } \\
\text { Cladosporium sp., Botrytis } \\
\text { sp., Fusarium sp. }\end{array}$ \\
\hline
\end{tabular}

